\title{
Indonesian National Security Policy in Fighting Terrorism Among the Youth Generation
}

\author{
Suharto Ladjide ${ }^{1}$, Pujo Widodo ${ }^{1}, \&$ Resmanto Widodo Putro ${ }^{1}$ \\ ${ }^{1}$ The Republic of Indonesia Defense University, Bogor, Indonesia \\ Correspondence: Suharto Ladjide, Doctoral Program, The Republic of Indonesia Defense University, Bogor \\ Indonesia. Tel: 62-818-0828-9337. E-mail: atto200@yahoo.com; suharto@idu.ac.id
}

Received: August 14, 2021

doi:10.5539/ass.v17n10p18
Accepted: August 30, $2021 \quad$ Online Published: September 19, 2021

URL: https://doi.org/10.5539/ass.v17n10p18

\begin{abstract}
At the beginning of the $21^{\text {st }}$ century, Indonesia was marked by terrorist attacks that caused victims, such as the Bali Bombings in 2002. The threat and violence of terrorism cannot be separated from the influence of international terrorist organizations that attack Indonesia through targeted attacks on vulnerable individuals or groups, more specifically the youth generation. The perpetrators of terrorism have taken advantage of the technological network of the online radicalization era. The Industrial Revolution 4.0 has inspired many patterns of human interaction from domestic interactions to global interactions. This study explains various ideas about implementing national security policies in countering terrorism among the youth generation with qualitative methods using literature analysis so that several tactical steps are found to counter terrorism through critical and open education, exemplary, eradicating injustice, transcendence, and international cooperation. An important finding in this study is the importance of the joint commitment of elements of society to implement Indonesia's national security policy through actions that have small dimensions in the school and household environment and large dimensions at the national level.
\end{abstract}

Keywords: national security, terrorism, youth generation

\section{Introduction}

Indonesia's national resilience is a dynamic condition that contains tenacity and resilience that contains the ability to develop national strength to face and overcome all challenges, threats, obstacles, and disturbances that come from within and outside the country in direct and indirect ways, endangering integrity, identity, and survival of the nation and state as well as the struggle to achieve national goals (Tim Pokja Lemhannas, 2020). Conditions that always develop in situations that are influenced by a dynamic strategic environment of volatility, uncertainty, complexity, and ambiguity, which are abbreviated as VUCA, due to the dynamic influence of the strategic environment. National security includes the concept of regulating ideological, political, economic, social, cultural, defense, and security aspects (Maharani, 2019).

At the beginning of the $21^{\text {st }}$ century, Indonesia has been the target of several terrorist attacks. The ones that claimed the most victims were the first and second Bali bombings. The first Bali bombing occurred on October $12^{\text {th }}, 2002$ in Kuta, Bali. The bomb killed 202 people, including 88 Australians and 38 Indonesians (Arnani, 2019). The latest ideological aberrations were found in East Kalimantan during the attack on the Daha Selatan Police Headquarters in June 2020 (Wismabrata, 2020). The perpetrators of the bombings were young people and were thought to have been exposed to Jemaah Islamiyah, a hardline Islamic group. They were eventually caught, and sentenced to death. Indonesia faces a complex and growing threat and violence of terrorism which is also influenced by international terrorist organizations, such as the Islamic State of Iraq and Syria (ISIS), Al-Qaeda, Moro National Liberation Front (MNLF) and the Abu Sayyaf Group (ASG), have entered and intends to attack Indonesia through targeted attacks and affect vulnerable individuals or groups in the country, namely the youth generation.

Indonesia is considered to have great potential for the threat of terrorism because of the many acts of terror that have occurred, also because one of the terrorist groups Jemaah Islamiyah (JI), which is most often suspected of being responsible for terror acts, is based in Indonesia. After the Bali Bombings in 2002 and the arrests of Amrozy, Imam Samudra, and Muklas, these events showed a strong relationship with the international terrorist network Al-Qaeda. Linking to international networks is an argument that the international community believes in. 
The United States government believes in the existence of the Al Qaeda network in Indonesia. Al-Qaeda is present in the Southeast Asian region through Jamaah Islamiah (JI). Most JI leaders are Indonesian people (Windiani, 2017). The case of terrorism in Indonesia even ranks fourth in the Asia Pacific region based on data released by the Global Terrorism Database in 2020. (Global Terrorism Database, 2021).

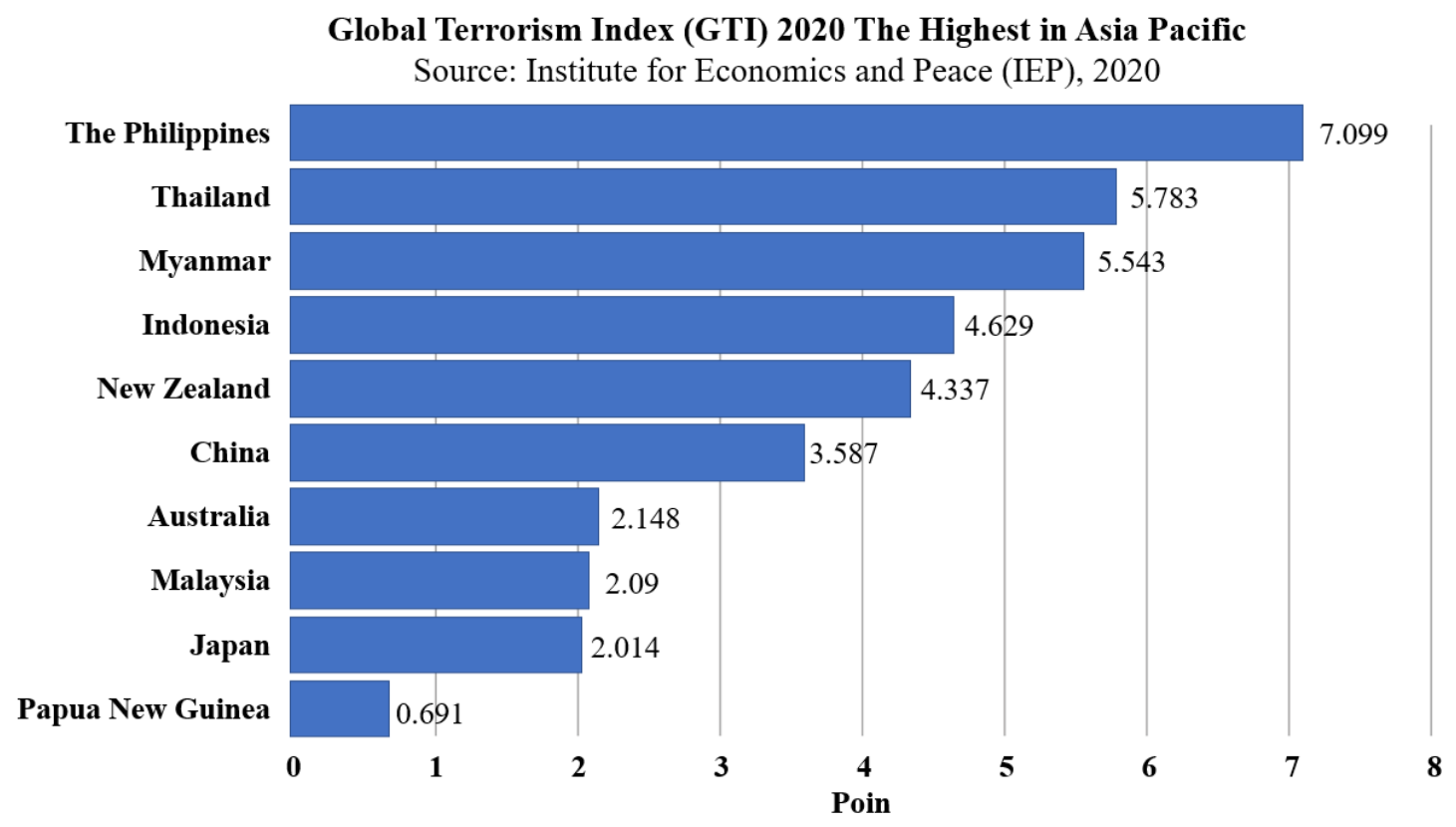

Figure 1. Global Terrorism Index (GTI) 2020 The Highest in Asia Pacific

(Source: Institute for Economics and Peace, 2020)

The perpetrators of terrorism have taken advantage of the era of online radicalization through information technology networks to encourage the youth generation to attack the diversity and dynamism of Indonesia's unity and integrity. The influence of the development of science and technology has brought fundamental changes. The phenomenon that arises is the leap in science and information technology that has been applied in various aspects of life. Advances in science and information technology based on the Industrial Revolution 4.0 have inspired many patterns of interaction between humans from local interaction patterns to global interactions, from between countries to people around the world in a short time. The pattern of global interactions affects the patterns of thinking and acting in daily life, thus bringing Indonesian youth to experience a civilizational setback (Armawi, 2007).

The definition of the crime of terrorism is considered an extraordinary act starting after the terror of the United States WTC Building in 2001. The international world is increasingly aggressive in fighting terrorism. The United Nations Forum in Vienna, Austria in 2000 even specifically chose the theme "The Prevention of Crime and The Treatment of Offenders" (Ardili Johan Kusuma, 2019).

The Indonesian government has an obligation and must strive to thwart the growth and development of terrorism among the youth generation by stopping infiltration from outside and integrating information and intelligence capabilities from various domestic stakeholders, such as the Indonesia Armed Forces (TNI), Indonesian National Police (Polri), local governments, and the private sector, as well as international partners, through critical and open education, exemplary in society, eradicating structural injustice, and transcendence.

\section{Method}

The role of every stakeholder from all levels will determine the success of a country and the international community in minimizing and limiting the development of terrorism. Based on the basis and discussion of the previous section, several comprehensive steps will be needed to tackle the problem of terrorism.

\section{Results and Discussion}

Behavior that is identified as terrorism is not new in the history of human civilization. The term terrorism appeared in history during the French Revolution on the occasion of the Committee on Public Health 
(Robespierre dan Saint Just), from 1791 to 1794 and was first used in a scientific work by Gunzburg in Brussels, 1930. Although it may seem archaic, the term is not at all silent. Terrorism has succeeded in creating debate at the global level and at the same time terrorism has changed the way how young people face life.

Any debate about the concept and phenomenon of terrorism gives rise to controversy, emotion, inaccuracies and confusion, to the extent that, as Louise Richardson puts it, the only certainty about terrorism is an act of intent to injure accompanied by an act of imposing its will to frighten as many people as possible around the world. Since September 11, 2001, the importance of the term terrorism has gained. (Morales \& Gabriela, 2012).

Terrorism is defined as a sequence of violent, premeditated and highly mediated acts, which deliberately target non-military targets to create fear and insecurity, impress the population and influence politicians with the intent to modify the decision process (to generate, to negotiate, to pay, to suppress) and fulfill predetermined stated objectives (political, economic or criminal).

The most central role in countering terrorism is in the policies and steps made by the government. The government is usually also the main target of acts of terrorism, either directly or indirectly.

Here are some tactical steps that need to be taken to counter terrorism, such as critical and open education, exemplary in society, eradicating injustice, transcendence, and international cooperation.
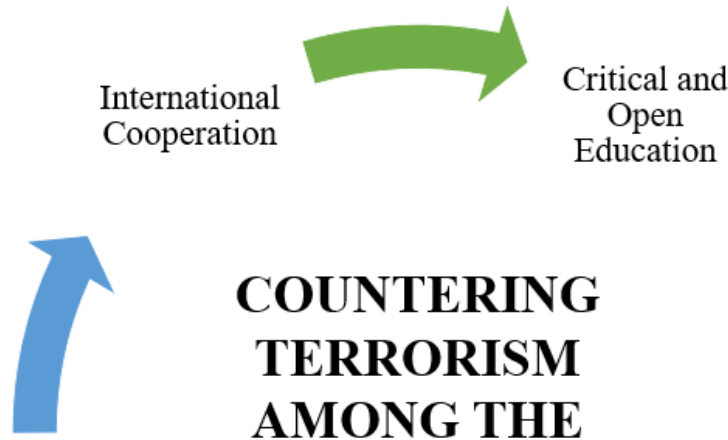

\section{COUNTERING} TERRORISM AMONG THE YOUTH Transcendence GENERATION $\begin{gathered}\text { Exemplary in } \\ \text { Society }\end{gathered}$
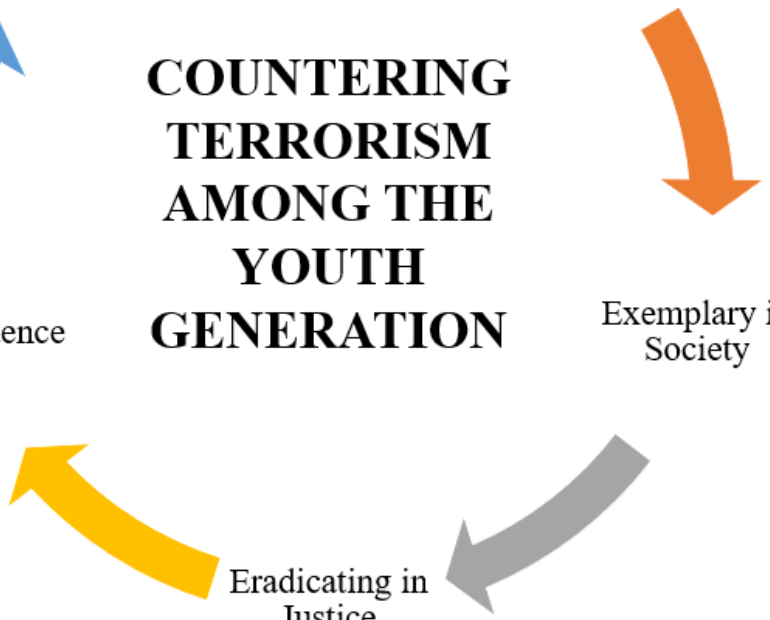

Figure 2. Counter-terrorism schemes among the youth generation (Source: Researchers, 2021)

\subsection{Critical and Open Education}

Critical and open formal education has an important role in the fight against the emergence of radical roots in the youth generation. Efforts in this direction can be detected because they are in line with the search for identity and the formation of social groups. The ideology of terrorism has taken away the happiness of the youth generation.

Therefore, formal educational institutions are responsible for the real conditions of the tendency of radicalism and acts of terror that grow in educational institutions. Ease of access to information is one of the entrances for propaganda of war, jihad, and the growth of extremism that fosters intolerance in thoughts, words and actions, as well as the potential for terrorism. The young age and the search for identity make it easier for the notion and ideas of terrorism to strengthen and take root among the youth.

Educational institutions that are at risk of fostering radicalism construct a single identity and reject other identities. Single identities and rejection of other identities tend to lead to an attitude of resistance so that group exclusivity emerges.

Benjamin Samuel Bloom has a taxonomy concept of education which includes three domains, namely cognitive, affective, and psychomotor. Cognitive are matters relating to intelligence or intellectual skills (logic), affective 
are matters relating to intelligence or personality attitude skills (ethics/politeness), and psychomotor are matters relating to intelligence or motoric and mechanical skills. Jean Piaget in the theory of cognitive development says that education must be in accordance with human development. This means that education must always pay attention to two things at once, namely the development or ability of every human being and pay attention to the dynamics that develop in society which includes science, technology, and culture. Along with the dynamics of life which is marked by increasingly sophisticated technology, increasingly complex life problems, and the increasing demands of society, it should be followed by intelligence in carrying out the educational process so that education is not left behind with the dynamics of social life (Muchith, 2016).

According to Law Number 20 of 2003 concerning the National Education System, Article 1 paragraph (1), education is a conscious and planned effort to create a learning atmosphere and learning process so that students actively develop their potential to have religious spiritual strength, self-control, personality, intelligence, noble character, and skills needed for themself, their community, their nation, and their country.

Educational institutions are a vital aspect of human life aimed at humanizing humans in a humane way so that an order of mutual respect and respect is realized. This idealism must be fully implemented according to expectations while remaining a critical and open vehicle by means of developing frameworks and programs to foster moderate and tolerant attitudes in countering the dangers of terrorism. Frameworks and programs are implemented in simple forms, such as allocating time for public lectures (joint lessons) on terrorism crimes from the National Counterterrorism Agency (BNPT), the Armed Forces, or the Police; involving the role of psychology teachers/lecturers to convey information and understanding about youth and positive self-discovery by providing opportunities for students to express their opinions and feelings openly; accommodate, direct, and supervise extracurricular activities as normal activities and invite students to think positively, work together, discuss, work together, the spirit of unity, and take care of each other and have the courage to refuse terrorism crimes. Educational institutions have a goal to achieve religious spiritual strength, self-control, have a personality, and have the intelligence, morals, and skills needed by the students, their society, their nation, and their state.

\subsection{Exemplary in Society}

In essence, terrorism is a matter of cultural conflict in a culturally plural society group that can be prevented through preventive and pre-emptive actions through legal culture and local wisdom. Legal culture and local wisdom are instrumental solutions that create role models in diluting the atmosphere in the life of society, nation and state to make it more harmonious. All components of society must be responsible for finding effective solutions to become pioneers in breaking the chain of terrorism in Indonesia. Community leaders, religious leaders, and traditional leaders can work together and synergize to form the values of nationalism and nationality in the youth generation.

In legal culture and local wisdom, the level of obedience and trust of the youth generation is still very high $(63.60 \%)$ to the example of community leaders, religious leaders, and traditional leaders (Hidayat \& Sugiarto, 2020). The figures have become role models to be followed and imitated by the youth generation. Local wisdom applies exemplary leadership based on a system of human values, tolerance, greatness of soul, democracy, and freedom of opinion. Local culture teaches the main values of life, such as justice, honesty, and truth.

The existence of a cultural community is likely to increase awareness of the youth generation to find their Indonesian identity and influence the desire to innovate to form social resilience through pride in local identity, solidarity, strengthening a sense of belonging, and pride as a nation. The existence of a cultural community within the youth generation is expected to create an effective deterrent to tackle terrorism.

In the context of prevention, the legal culture of the community has the responsibility to provide socialization and ideological strengthening as well as services for detecting the potential for radicalism, as well as supervising the association between young people in order to prevent understanding that leads to the doctrine of terrorism.

\subsection{Eradicating in Justice}

Finding the problem that is at the root of the problem of terrorism is not an easy job, but it is by no means without a solution. One of the root causes is injustice or inequality. Injustice is a hidden and latent factor whose existence is very important and decisive for the growth and development of terrorism activities. Deputy Secretary General of the Indonesian Ulema Council (MUI) Amirsyah Tambunan said that one of the triggers for acts of terrorism was state injustice in politics, economy, social and culture, which led to social inequality (Rajasa, 2016). The Rector of the University of Muhammadiyah Prof. Dr. Hamka (Uhamka) Suyatno assessed that radicalism and terrorism movements did not arise by themselves. Radicalism arises because the government fails to create a sense of justice for the people. Radicalism because there is no justice in the hands of the people, 
then the phenomenon of terrorism and radicalism will appear. This injustice can be seen from the widening gap between the rich and the poor, then angry and desperate to take radical actions to terrorism (Ihsanuddin, 2018).

Terrorist activities use the issue of injustice as one of the central factors. Injustice can be influenced by global, regional and national perspectives. Injustice in a global perspective is seen in the attitude of America and European countries towards Israel and Palestine.

Injustice in a regional perspective is the attitude of a country towards other countries sometimes also provokes terrorism efforts. The progress of certain countries has the potential to trigger jealousy and give birth to terror efforts, especially if their interests are disturbed. The progress of Singapore and Malaysia in the past compared to the east coast of Sumatra Island gave rise to the seeds of terrorism against ships sailing in the Malacca Strait. Injustice from a national perspective is reflected in the unfair treatment of certain groups who are dissatisfied with government policies.

Terrorism is the action of a reaction, so to prevent increasingly sophisticated acts of terrorism, it would be better if we evaluate the things that trigger terrorism. It should be remembered that acts of terrorism are also increasingly sophisticated with new methods and ways, even more terrible if future acts of terrorism use unmanned systems to take control of nuclear power.

Therefore, every country needs to be more open and communicate with neighboring countries more intensively and eliminate injustice and inequality so that the gap will not widen. If the gap of injustice and inequality gets wider, acts of terrorism will also intensify with patterns and actions that are sometimes unexpected. The bombing of the WTC Twin Towers in America, which is famous for the events of March $11^{\text {th }}$, is a lesson that may not have been predicted before. The form of terrorism prevention strategy is the need for education and culture.

\subsection{Transcendence}

Having a comprehensive understanding of the acts of terrorism conducted by the youth generation and the tactics to counter them is absolutely necessary. The deviation of values among the youth generation is based on sophisticated and globalized information technology. Nowadays, the younger generation is likely more intelligent and has critical thinking than the older one. However, they are still unstable in seeking self and group identity. If the deviation increases, then acts of terrorism by the youth generation will spread fear and act of undirected violence.

Transcendence comes from the Latin transcendentia, which means beyond and is often used in philosophy, religion, and theology to describe the relationship between man and his God. God is transcendent, because it transcends the human being who is His creation. The opposite of transcendent is immanent, that is, something that is close to the everyday world of humanity, without connection with anything greater than it (Wattimena \& Arifin, 2018).

Transcendence thinking is no longer only about self, family or group, but also thinking from the perspective of the whole. Transcendence emphasizes empathy, namely the ability to feel and see the world from the perspective of others. Both are basic elements for the creation of cosmopolitanism consciousness. Transcendence ability is the human ability to see the world with a wider lens than self, family or group interests.

Therefore, the step of transcendence empathy is important as an effort to counter the influence of terrorism among the youth generation, starting from increasing national security to changing the paradigm of the national education system. However, the most basic and effective step is to build a transcendence mindset, namely a mindset that transcends the barriers of difference and touches the overall point of view.

The transcendent concept is implemented by always conveying 'Truth, Immortality, and Goodness' through religious and philosophical education as well as exemplary community leaders, religious leaders, and traditional leaders. Transcendence can be used as an antidote to terrorism among the youth generation by providing guidance that focuses and attaches attention to the activities of extracurricular groups and prevents the entry of non-organic organizations in campuses and schools. The youth generation is invited to think openly, no longer only about themselves, their families or their groups, so that a sense of empathy grows on how to feel and see the world from the perspective of others.

\subsection{International Cooperation}

The terrorist act of September 11, 2001 in the United States shows that terrorism has become global. Therefore, it is important to carry out international cooperation. International terrorism is a political act that aims to create dramatic and fatal damage to civilians and create an atmosphere of fear (terror) for political, ideological, secular, and/or religious reasons. Terrorism is against the universally accepted principles of law, order, human rights and 
peaceful resolution of disputes. Terrorism has used terror as a tactic around the world, regardless of the wealth, gender or age of its victims, most of whom are civilians (Brieger, 2011).

The crime of terrorism has deeply disturbed the public and governments in various countries around the world. The crime of terrorism is seen from a legal perspective as an extraordinary crime and is considered an enemy of mankind. Therefore, security cooperation in the context of tackling terrorism is deemed necessary through regional and global organizations.

The widespread impact of terrorism has made Indonesia and ASEAN countries have a common interest in actively participating in solving this problem. Discussion forums and cooperation in combating terrorism that have been initiated by the Indonesian government include the ASEAN Ministerial Meeting on Transnational Crime (AMMTC), which is a meeting forum under ASEAN to discuss transnational crime issues. In addition, Indonesia can take advantage of the ASEAN Regional Forum (ARF), which is a forum for ASEAN cooperation in addressing regional security issues. Apart from ASEAN, the ARF also consists of the United States, Russia, China and Japan. The establishment of the ASEAN Charter can also support ASEAN cooperation, in dealing with the problem of terrorism and to strengthen cooperation, ASEAN has also drafted and signed the ASEAN Convention On Counter Terrorism (ACCT), during the 12th Summit in Cebu, Philippines, on January $13^{\text {th }}, 2007$ (Setiawati, 2015).

Forms of international cooperation that accommodate the activities of the youth generation can be arranged through various programs, such as student exchanges, educational scholarships, workshops, and campus training. Larger efforts can be developed through the Sister Campus or Sister School collaborative program, which has the potential to be developed into the ASEAN University Network program. Youth cooperation through the ASEAN Socio-Cultural Community (ASCC) through the activities of the ASEAN Sports Week, ASEAN Cultural Week, and ASEAN Women's Solidarity at the student or student level. The ASEAN Community which has been agreed since 2015 aims to build a harmonious, prosperous, and integrated ASEAN community in the political, economic, social, and cultural fields (ASEAN, 2019). Cooperation in the ASEAN community framework will have an effect on social development that will prevent the youth generation from being exposed to radicalism to terrorism.

\section{Conclusion}

The prevention of terrorism among the youth generation needs to be addressed with the policies of the Indonesian government in the field of national security, one of which is the policy of not giving mercy to anyone involved in terrorism.

The government needs to involve community leaders, religious leaders, and traditional leaders as well as families to continuously deliver guidance through formal and non-formal education in an effort to prevent terrorism among the youth generation. The family plays a very important role in character building, where a set of social and ethical rules must be applied from home.

National security policies are implemented in tactical steps through critical and open education, exemplary in society, eradicating injustice, transcendence, and international cooperation to the youth generation in order to create a dynamic and tenacious Indonesian national resilience in order to deal with the environmental influences that are volitile, uncertain, complex, and ambiguous.

\section{References}

Armawi, A. (2007). Revitalisasi Pancasila dalam Konteks Nation and Character Building. Jurnal Ketahanan Nasional Volume XII Nomor, 3, 59-70.

Arnani, M. (2019). Hari Ini dalam Sejarah: Tragedi Bom Bali II, 23 Orang Meninggal. Retrieved from https:/www.kompas.com/tren/read/2019/10/01/061000565/hari-ini-dalam-sejarah-tragedi-bom-bali-ii-23-or ang-meninggal?page=all

ASEAN. (2019). ASEAN Regional Retrieved from https://asean.org/asean-political-security-community/asean-regional-forum-arf/

Brieger, P. (2011). What is Al Qaeda? Terrorism. Madrid: Clave Intelectual.

Global Terrorism Database. (2021). Dampak Terorisme di Indonesia Tertinggi Keempat di Asia Pasifik. Retrieved from https://databoks.katadata.co.id/datapublish/2021/03/29/dampak-terorisme-di-indonesia-ter tinggi-keempat-di-asia-pasifik

Hidayat, A., \& Sugiarto, L. (2020). Strategi Penangkalan dan Penanggulangan Radikalisme melalui Cultural Reinforcement Masyarakat Jawa Tengah. Jurnal USM Law Review, 3(1), 135-154. 
https://doi.org/10.26623/julr.v3i1.2203 .

Ihsanuddin. (2018). Radikalisme Muncul karena Ketidakadilan. Retrieved from https://amp.kompas.com/nasional/read/2018/02/28/16544961/radikalisme-muncul-karena-ketidakadilan

Kusuma, A. J., Warsito, T., Surwandono, \& Muhammad, A. (2019). Indonesia dan Ancaman Terorisme: Dalam Analisis Dimensi Imaterial. Jurnal Ilmu-ilmu Sosial dan Humaniora, 333-341. https://doi.org/10.24198/sosiohumaniora.v21i3.21142

Maharani, S. D. (2019). Indeks Ketahanan Ideologi Pancasila. Jurnal Ketahanan Nasional, 287-295.

Morales, R., \& Gabriela, T. (2012). El terrorismo y nuevas formas de terrorismo. Espacios Públicos, 15(33), $72-95$.

Muchith, M. S. (2016). Radikalisme dalam Dunia Pendidikan. ADDIN, 10(1), 163-180. https://doi.org/10.21043/addin.v10i1.1133

Rajasa, M. A. (2016). Ketidakadilan Picu Terorisme. Retrieved from https://m.mediaindonesia.com/politik-dan-hukum/48497/ketidakadilan-picu-terorisme

Setiawati, D. D. (2015). Peran ASEAN dalam Memberantas Tindak Pidana Terorisme di Kawasan Asia Tenggara Berdasarkan Convention On Counter Terorism. JOM Fakultas Hukum, 2(1), 1-10.

Tim Pokja Lemhannas. (2020). Bahan Ajar Bidang Studi Geostrategi dan Ketahanan Nasional. Jakarta: Lemhannas.

U.S. Department of Homeland Security. (2019). Strategic Framework for Countering Terrorism and Targeted Violence. Washington D.C.: U.S. Department of Homeland Security.

Wattimena, R. A., \& Arifin, B. (2018). Melampaui Terorisme: Pendekatan Komprehensif untuk Memahami dan Menangkal Terorisme. Jurnal Ilmu Hubungan Internasional MANDALA, 1(1), 38-55.

Windiani, R. (2017). Peran Indonesia dalam Memerangi Terorisme. Jurnal Ilmu Sosial, 16(2), 135-152. https://doi.org/10.14710/jis.16.2.2017.135-152

Wismabrata, M. H. (2020). Teror di Polsek Daha Selatan, Pelaku Berusia 19 Tahun dan Temukan Bendera Hitam ISIS. Retrieved from https://regional.kompas.com/read/2020/06/02/06020081/teror-di-polsek-dahaselatan-pelaku-berusia-19-tahun-dan-temukan-bendera?page=all

\section{Copyrights}

Copyright for this article is retained by the author(s), with first publication rights granted to the journal.

This is an open-access article distributed under the terms and conditions of the Creative Commons Attribution license (http://creativecommons.org/licenses/by/4.0/). 